\title{
Unfolding Extraordinary Positive Effect of High Temperature and High Irradiance on DC Power Output of a Multicrystalline PV Module: A Case Study of Western Rajasthan
}

\author{
Shalini Garg \\ Government Polytechnic College, Jodhpur, India
}

\begin{abstract}
The solar cell generates voltage when exposed to sunlight, producing direct current electricity, the power being equal to product of current and voltage. Literature and research papers shows negative temperature coefficient for both dc voltage and $\mathrm{dc}$ power for cell temperature greater than $25^{\circ} \mathrm{C}$. However, no attempt has yet been made to visualise and evaluate as to how the dc voltage, dc current and dc power varies with irradiance and temperature acting concurrently on the PV module. This paper evaluates the relative contribution of temperature and irradiance particularly POA (Plane of Array Irradiance) acting concurrently on the dc power output of a multicrystalline PV module. The cell temperature varies linearly with irradiance but due to the dominating effect of high irradiance relative to slight increase in temperature, a multicrystalline PV module gives outstanding performance at high cell temperature and high irradiance, showing remarkably overall positive effect of high cell temperature and high irradiance. In contrast to literature this paper brings forward two most vital facts. Firstly, dc power increases with increase in temperature and maximum dc voltage about $80 \%$ of its rated value is obtained at cell temperature $58.14^{\circ} \mathrm{C}$. Secondly, despite the negative temperature coefficient of voltage for cell temperature greater than $49^{\circ} \mathrm{C}$ instead of $25^{\circ} \mathrm{C}$, significant dc voltage and dc power is obtained only for cell temperature greater than $49^{\circ} \mathrm{C}$. This paper also explores the input condition required to obtain high energy yield.
\end{abstract}

\section{General Terms}

Solar Irradiance, Energy yield, Grid connected PV power plant, Western Rajasthan.

\section{Keywords}

Multicrystalline PV module; Plane of array irradiance (POA); Cell temperature; DC voltage; DC power; Efficiency.

\section{INTRODUCTION}

The performance of a PV system depends on its basic characteristic, system design, location and climatic conditions of the site. Among the various climatic parameters like temperature, irradiance, cloud coverage, humidity and wind speed, irradiance and temperature are the two most important parameters affecting the efficiency of PV power plant. [1,2]. Several studies have been conducted in various parts of the world but so far no such investigation has been done for Western Rajasthan. This paper evaluates joint effect of irradiance and temperature the two major environmental parameters on the dc voltage, current and power output of a multicrystalline PV module for the climatic conditions of Western Rajasthan. Western Rajasthan commonly known as 'Thar Desert' has around 208000 square $\mathrm{Km}$ of flat desert

\author{
Arun J. B. \\ Teacher's Training Center, Jodhpur, India
} with clear sunny days greater than 325 , together with high temperature.

Literature and many researchers show that module efficiency decreases with increase in temperature due to negative effect of temperature on voltage although current has slight positive effect. This is because they have considered variation in voltage and current with temperature keeping irradiance constant. However, both voltage and current and in turn power depends upon the relative contribution of cell temperature and irradiance acting together.

Some of the authors have evaluated performance of PV plant with varying environmental conditions and show positive linear relationship of module efficiency with temperature. Bhattacharya et al. [3] have shown that a strong positive correlation exists between ambient temperature and module efficiency for a monocrystalline solar photovoltaic module located in Tripura. Vasisht et al. [4] have shown that ambient temperature between 20 to $38^{\circ} \mathrm{C}$ has positive correlation with the efficiency of a monocrystalline PV system. The results of Garg et al. [5] also show that dc voltage decreases with increase in temperature only for ambient temperature greater than $38^{\circ} \mathrm{C}$ and cell temperature greater than $50^{\circ} \mathrm{C}$. Garg et al. [6] have shown that dc power output varies in direct proportion to irradiance outweighing the change in temperature. Power output at cell temperature $50-55^{\circ} \mathrm{C}$ was far greater than power output at $40^{\circ} \mathrm{C}$. Garg and JB [7] have also shown that dc voltage attains a point of saturation maintaining nearly constant value in the range of $80-85 \%$ of its rated value for cell temperature greater than $49^{\circ} \mathrm{C}$. Mustapha et al. [8] while evaluating the performance of a polycrystalline solar photovoltaic module under MaiduguriNigeria weather conditions have shown that current generated is directly proportional to solar irradiance and is almost independent of temperature. The maximum rated power was achieved during the sunniest month and module current increased by $0.1 \mathrm{~A} /{ }^{\circ} \mathrm{C}$ with increase in temperature, while module voltage decreased by $0.05 \mathrm{~V} /{ }^{\circ} \mathrm{C}$ leading to increase in power with increase in temperature.

Many authors $[2,9,10]$ have reported more power yield in summer compared to winters. Babatunde and Abbasoglu [10] while evaluating a power plant in Northern Cyprus found that energy production in summer was $111 \%$ higher than in winters and concluded that long duration of high solar radiation outweighs the negative effect of temperature. Panagea et al. [11] have shown that relative contribution of temperature and irradiance varies from region to region. In some cases, the two parameters mutually compensate each other. In some region like Eastern Greece the effect of 
temperature is negative, while in Western Greece the effect of temperature is outweighed by significant increase in radiation and lower cloud coverage, increasing power by $4-5 \%$.

\section{METHODOLOGY}

The data and result correspond to of the $5 \mathrm{MW}$ grid connected PV power plant located at Ramgarh, in district Jaisalmer of Western Rajasthan. The analysis is based on the average reading of five array with maximum rated dc voltage, maximum rated dc current and maximum rated dc power being equal to $735.36 \mathrm{~V}, 161.4 \mathrm{~A}$ and $118.687 \mathrm{KW}$ respectively at STC conditions.

i. The data corresponds to data over a period of one year from September 2015-August 2016.

ii. In real field cell temperature varies linearly with irradiance and concurrent effect of temperature and irradiance is evaluated by analysing various parameters on daily basis in the same time interval.

iii. The dc power, dc voltage, dc current, cell temperature, ambient temperature and plane of array irradiance are designated as $\mathrm{P}_{\mathrm{dc}}, \mathrm{V}_{\mathrm{dc}}, \mathrm{I}_{\mathrm{dc}}, \mathrm{T}_{\mathrm{c}}, \mathrm{T}_{\mathrm{amb}}$ and POA respectively.

iv. $\mathrm{P}_{\mathrm{dc}}$ is evaluated in the time interval when $\mathrm{V}_{\mathrm{dc}}$ experiences negative effect of temperature.

v. The $\mathrm{V}_{\mathrm{dc}}$ experiences negative effect of temperature for cell temperature greater than $48-49^{\circ} \mathrm{C}$. The cell temperature increases with increasing POA and decreases with decreasing POA. However, as the cell temperature cannot change instantaneously there is a short duration of about half an hour soon after POA starts reducing for which cell temperature increases with decreasing POA. In this interval $\mathrm{P}_{\mathrm{dc}}$ reduces slightly due to increase in temperature and decrease in POA but is insignificant and is not considered in this paper.

vi. $\quad \mathrm{V}_{\mathrm{dc}}, \mathrm{I}_{\mathrm{dc}}$ and $\mathrm{P}_{\mathrm{dc}}$ are evaluated in $\%$ with reference to their maximum rated value and are designated as $V_{r}, I_{r}$ and $P_{r}$ respectively.

In particular

$\mathrm{V}_{\mathrm{r}}=\left(\mathrm{V}_{\mathrm{dc}} d \mathrm{~V}_{\text {rated }}\right) * 100 ; \mathrm{I}_{\mathrm{r}}=\left(\mathrm{I}_{\mathrm{dc}} / \mathrm{I}_{\mathrm{rated}}\right) * 100 ; \mathrm{P}_{\mathrm{r}}=$ $\left(\mathrm{P}_{\mathrm{dc}} / \mathrm{P}_{\text {rated }}\right) * 100$.

vii. Change in $\mathrm{V}_{\mathrm{dc}}, \mathrm{I}_{\mathrm{dc}}, \mathrm{P}_{\mathrm{dc}}, \mathrm{POA}, \mathrm{T}_{\mathrm{amb}}$ and $\mathrm{T}_{\mathrm{c}}$ are designated as $\Delta \mathrm{V}, \Delta \mathrm{I}, \Delta \mathrm{P}, \Delta \mathrm{POA}, \Delta \mathrm{T}_{\mathrm{amb}}$ and $\Delta \mathrm{T}_{\mathrm{c}}$ where

- $\Delta \mathrm{V}=\mathrm{V}_{2}-\mathrm{V}_{1} ; \mathrm{V} 1=\mathrm{V}_{\mathrm{dc}}$ at time $\mathrm{X}_{1} ; \mathrm{V}_{2}=\mathrm{V}_{\mathrm{dc}}$ at time $\mathrm{X}_{2}$;

- $\Delta \mathrm{I}=\mathrm{I}_{2}-\mathrm{I}_{1} ; \mathrm{I}_{1}=\mathrm{I}_{\mathrm{dc}}$ at time $\mathrm{X}_{1} ; \mathrm{I}_{2}=\mathrm{I}_{\mathrm{dc}}$ at time $\mathrm{X}_{2}$;

- $\Delta \mathrm{P}=\mathrm{P}_{2}-\mathrm{P}_{1} ; \mathrm{P}_{1}=\mathrm{P}_{\mathrm{dc}}$ at time $\mathrm{X}_{1} ; \mathrm{P}_{2}=\mathrm{P}_{\mathrm{dc}}$ at time $\mathrm{X}_{2}$;

- $\triangle \mathrm{POA}=\mathrm{POA}_{2}-\mathrm{POA}_{1} ; \mathrm{POA}_{1}=\mathrm{POA}$ at time $\mathrm{X}_{1} ; \mathrm{POA}_{2}$ $=$ POA at time $\mathrm{X}_{2}$;

- $\Delta \mathrm{T}_{\mathrm{amb}}=\mathrm{T}_{\mathrm{amb} 2}-\mathrm{T}_{\mathrm{amb} 1} ; \mathrm{T}_{\mathrm{amb} 1}$ is cell temperature at time $\mathrm{X}_{1} ; \mathrm{T}_{\mathrm{amb} 2}$ is cell temperature at $\mathrm{X}_{2}$

- $\Delta \mathrm{T}_{\mathrm{c}}=\mathrm{Tc}_{2}-\mathrm{T}_{\mathrm{c} 1} ; \mathrm{T}_{\mathrm{c} 1}$ is cell temperature at time $\mathrm{X}_{1} ; \mathrm{T}_{\mathrm{c} 2}$ is cell temperature at $\mathrm{X}_{2}$

- $\mathrm{X}_{2}-\mathrm{X}_{1}$ represents the only time interval when $\mathrm{V}_{\mathrm{dc}}$ experiences negative effect of temperature.

viii. Percentage change in $\mathrm{V}_{\mathrm{dc}}, \mathrm{I}_{\mathrm{dc}}$ and $\mathrm{P}_{\mathrm{dc}}$ with reference to their maximum rated value are designated as $\Delta \mathrm{V}_{\mathrm{r}}, \Delta \mathrm{I}_{\mathrm{r}}$ and $\Delta \mathrm{P}_{\mathrm{r}}$

Where

$\Delta \mathrm{V}_{\mathrm{r}}=\left(\Delta \mathrm{V} / \mathrm{V}_{\text {rated }}\right) * 100 ; \Delta \mathrm{I}_{\mathrm{r}}=\left(\Delta \mathrm{I} /{ }_{\text {Irated }}\right) * 100 ; \Delta \mathrm{P}_{\mathrm{r}}=$ $\left(\Delta \mathrm{P} / \mathrm{P}_{\text {rated }}\right) * 100$

ix. Weather monitoring station, pyranometer, and SCADA (Supervisory Control and Data Acquisition) are used to record and store various data.

$\mathrm{x}$. The irradiance considered is the irradiance incident on the plane of the array- POA instead of GHI.

xi. The effect of other climatic parameters like wind speed and humidity have not been considered.

\section{EXPERIMENTAL DATA ANALYSIS}

The joint effect of temperature and irradiance on dc voltage, dc current and dc power output of a multicrystalline PV plant are visualised by plotting various parameters with respect to time on daily basis when Western Rajasthan experiences long duration of very high irradiance and correspondingly high temperature. Data is also analysed for the month having lowest temperature and lowest irradiance. The results for all dates in a month having similar weather conditions are almost similar although specific dates of the month have been chosen randomly.

\subsection{Concurrent effect of temperature and irradiance on $P_{d c}, V_{d c}$ and $I_{d c}$ for $13^{\text {th }}$ May 2016}

Effect of temperature on $V_{d c}$ in the time interval when $V_{d c}$ experiences negative effect of temperature is analysed. The effect of irradiance on $I_{d c}$ in the same time interval is analysed. Relative contribution of temperature and irradiance on $\mathrm{P}_{\mathrm{dc}}$ is evaluated by visualising and analysing $\mathrm{P}_{\mathrm{dc}}$ in the same time interval.

\subsubsection{Effect of temperature on $V_{d c}$ for $13^{\text {th }}$ May 2016}

Literature shows that with increase in cell temperature above $25^{\circ} \mathrm{C}$ there is substantial drop in voltage while the while voltage variations are very small with increase in irradiance $[12,13]$. However, in contrast the real field analysis shows entirely different results as shown in figure 1 .

The effect of high cell temperature on $V_{\mathrm{dc}}$ has been analysed by considering three different dates of the month having very high temperature for long duration. The time with corresponding POA over the interval when $\mathrm{V}_{\mathrm{dc}}$ is reducing is marked in figure1.

The graphs of figure 1 and 2 demonstrate following attributes.

- Starting from the wake-up voltage $\mathrm{V}_{\mathrm{dc}}$ drops rapidly as the sun begins to rise but very soon it starts increasing rapidly with increasing POA and increasing cell temperature. In the time duration $8: 17: 42$ to $10: 16: 28, \mathrm{~V}_{\mathrm{dc}}$ increases as POA increases from $373.58 \mathrm{~W} / \mathrm{m}^{2}$ to $733.01 \mathrm{~W} / \mathrm{m}^{2}$, cell temperature increases from $39.87^{\circ} \mathrm{C}$ to $49.15^{\circ} \mathrm{C}$, reaching point of saturation, attaining $631.16 \mathrm{~V}$ nearly $85 \%$ of its rated value at ambient temperature $37.90^{\circ} \mathrm{C}$ and cell temperature $49.15^{\circ} \mathrm{C}$ as shown in figure 1 . The corresponding value of POA is equal to $733.01 \mathrm{~W} / \mathrm{m}^{2}$ and is marked in figure 2 .

- The negative effect of temperature on $\mathrm{V}_{\mathrm{dc}}$ voltage is observed only in the time interval $10: 16: 28$ to $12: 44: 55$ after $\mathrm{V}_{\mathrm{dc}}$ attains saturation and cell temperature is greater than $49^{\circ} \mathrm{C}$ with corresponding increase in POA from $733.01 \mathrm{~W} / \mathrm{m}^{2}$ to $916.81 \mathrm{~W} / \mathrm{m}^{2}$. In this interval the following attributes are observed and are shown vide figure 1-

(i) Cell temperature increases from $49.15^{\circ} \mathrm{C}$ to $59.97^{\circ} \mathrm{C}$

(ii) Ambient temperature increasing from $37.90^{\circ} \mathrm{C}$ to $41.98^{\circ} \mathrm{C}$

(iii) $\mathrm{V}_{\mathrm{dc}}$ reduces from $631.16 \mathrm{~V}$ to $601.07 \mathrm{~V}$ i.e. from $85.8 \%$ to $81.73 \%$ of its rated value but still $\mathrm{V}_{\mathrm{dc}}$ is significant compared to its value for cell temperature less than $49^{\circ} \mathrm{C}$. 


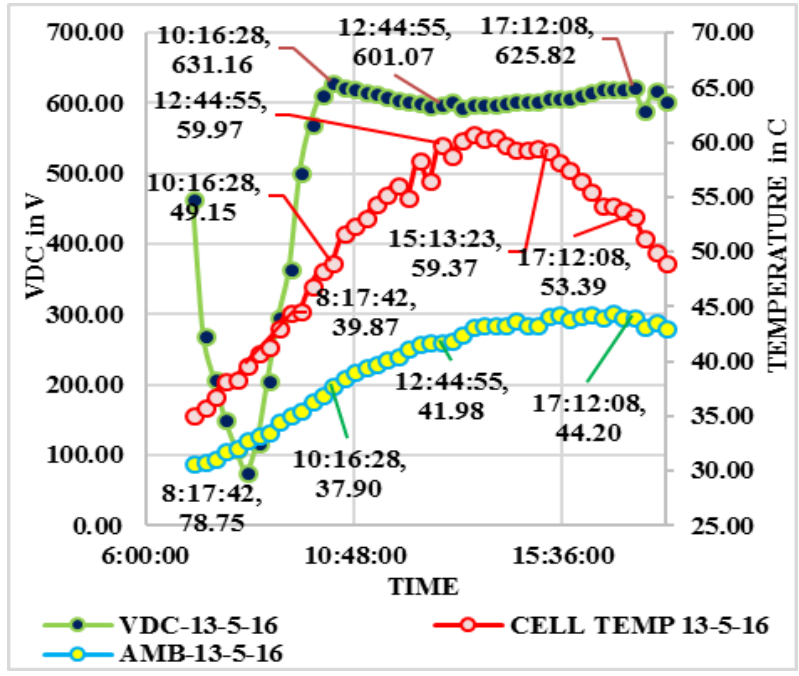

Figure 1- Variation of $V_{d c}, T_{c}$ and $T_{a m b}$ with respect to time for $13^{\text {th }}$ of May 2016

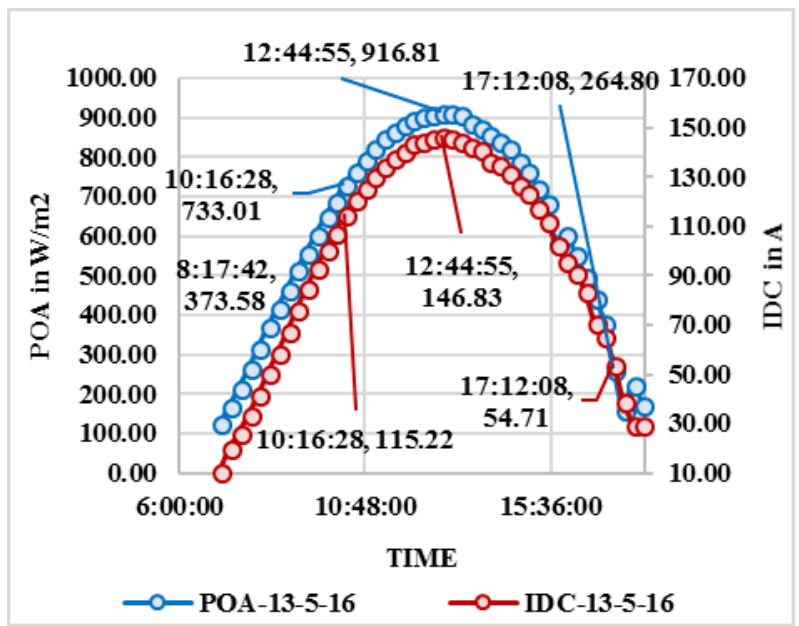

Fig-2 Variation of POA and $I_{\mathrm{dc}}$ with respect to time for $13^{\text {th }}$ of May 2016

- With decreasing POA, cell temperature starts reducing consequently $\mathrm{V}_{\mathrm{dc}}$ starts increasing although ambient temperature continues to increase. $\mathrm{V}_{\mathrm{dc}}$ increases from 601.07 to $625.87 \mathrm{~V}$ as cell temperature reduces gradually from 59.97 ${ }^{\circ} \mathrm{C}$ to $53.39^{\circ} \mathrm{C}$ showing that $\mathrm{V}_{\mathrm{dc}}$ is governed by cell temperature and not ambient temperature.

Thus, despite the negative effect of temperature on dc voltage, it remains within $85-80 \%$ of its rated value which is very high compared to $\mathrm{V}_{\mathrm{dc}}$ at cell temperature less than $49^{\circ} \mathrm{C}$, making negative effect of temperature almost insignificant. In fact, in contrast to literature, this itself is the most remarkable positive effect of high temperature.

\subsubsection{Effect of irradiance on $I_{d c}$ for 13th May 2016}

Literature shows that at constant cell temperature $\left(25^{\circ} \mathrm{C}\right)$, current increases in direct proportion to irradiance and increases slightly with increase in temperature $[12,13]$. In real field the increase in irradiance is so large compared to increase in temperature that $I_{d c}$ varies linearly with POA irrespective of temperature showing strong dependence on irradiance.
In the time interval $10: 16: 28$ to $12: 44: 55$ when $V_{d c}$ shows negative effect of cell temperature there is significant increase in POA from $733.01 \mathrm{~W} / \mathrm{m}^{2}$ to $916.81 \mathrm{~W} / \mathrm{m}^{2}$ although increase in cell temperature is only $10^{\circ} \mathrm{C}$, the result is perfectly linear increase of $\mathrm{I}_{\mathrm{dc}}$ with POA from $115.22 \mathrm{~A}$ to $146.83 \mathrm{~A}$ shown vide figure 2 .

\subsubsection{Joint Effect of temperature and irradiance on $P_{d c}$}

The joint effect of two parameters is observed in the time interval when $V_{d c}$ experiences negative effect of temperature.

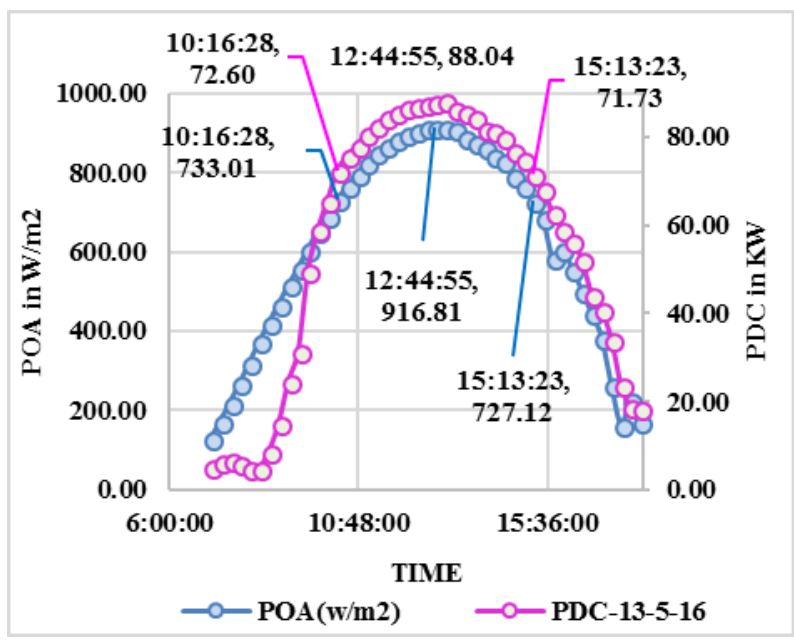

Figure 3- Variation of $P_{d c}$ and POA with time for $13^{\text {th }}$ of May 2016

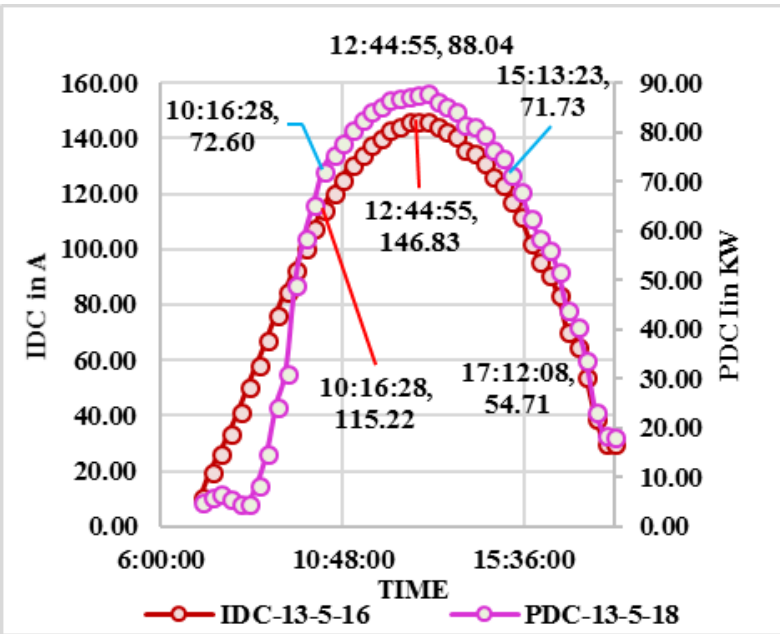

Figure 4- Variation of $I_{d c}$ and $P_{d c}$ with respect to time for $13^{\text {th }}$ May 2016 


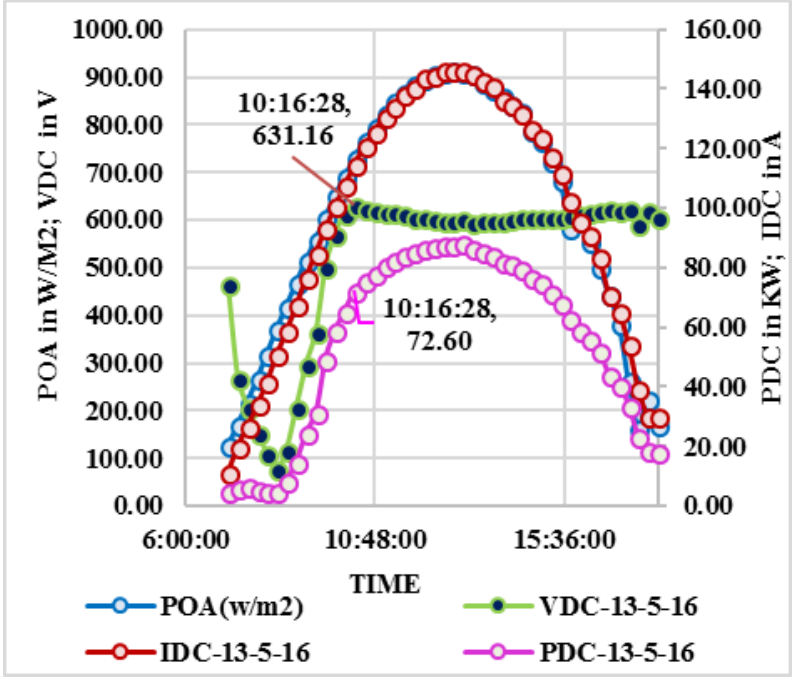

Figure 5- Variation of POA, $V_{d c}, I_{d c}$ and $P_{d c}$ with time for $13^{\text {th }}$ May 2016

In time duration 10:16:28 to $12: 44: 55$ when $\mathrm{V}_{\mathrm{dc}}$ decreases due to increase in temperature $\mathrm{I}_{\mathrm{dc}}$ increases due increase in POA. The increase in $I_{d c}$ is much greater than decrease in $V_{d c}$, the result is that $\mathrm{P}_{\mathrm{dc}}$ increases from $72.60 \mathrm{KW}$ to $88.04 \mathrm{KW}$ as shown in figure 3 .

Once $\mathrm{V}_{\mathrm{dc}}$ attains constant value variation in $\mathrm{V}_{\mathrm{dc}}$ are negligible compared to large variation in current due to large variation in irradiance compared to small variations in cell temperature. As a result, $\mathrm{P}_{\mathrm{dc}}$ varies in accordance to voltage until $\mathrm{V}_{\mathrm{dc}}$ attains the point of saturation. Thereafter it varies in accordance to POA and $\mathrm{I}_{\mathrm{dc}}$ as large variations in current now overtakes slight changes in voltage shown vide figure 4-5. The results are summarised in table 1 .

Table 1- Evaluation of relative contribution of Irradiance and temperature for $13^{\text {th }}$ of May 2016 on $P_{d c}$ in the time interval when $V_{d c}$ experiences negative effect of temperature.

\begin{tabular}{|c|c|c|c|c|c|c|c|c|c|}
\hline $\begin{array}{l}\text { Tim } \\
\text { e } \\
\text { inter } \\
\text { val }\end{array}$ & $\begin{array}{l}\mathbf{P O} \\
\mathbf{A} \text { in } \\
\mathbf{W} / \\
\mathbf{m}^{2}\end{array}$ & $\begin{array}{l}\text { Ambie } \\
\text { nt } \\
\text { tempe } \\
\text { rature } \\
\text { in }{ }^{\circ} \mathrm{C}\end{array}$ & $\begin{array}{l}\text { Cell } \\
\text { tempe } \\
\text { rature } \\
\text { in }{ }^{\circ} \mathrm{C}\end{array}$ & $\begin{array}{l}\mathbf{V}_{\mathrm{dc}} \\
\text { in } \\
\mathbf{V}\end{array}$ & $\begin{array}{l}\mathbf{V}_{\mathbf{r}} \\
\text { in } \\
\%\end{array}$ & $\begin{array}{l}\mathbf{I}_{\mathrm{dc}} \\
\text { in } \\
\mathrm{A}\end{array}$ & $\begin{array}{l}I_{r} \\
\text { in } \\
\%\end{array}$ & $\begin{array}{l}\mathbf{P}_{\text {dc }} \\
\text { in } \\
K \\
W\end{array}$ & $\begin{array}{l}P_{r} \\
\text { in } \\
\%\end{array}$ \\
\hline $\begin{array}{l}X_{1}= \\
10: 1 \\
6: 28 \\
\text { am }\end{array}$ & $\begin{array}{l}\text { PO } \\
A_{1}= \\
733 . \\
01\end{array}$ & $\begin{array}{l}\mathbf{T}_{\mathrm{amb1} 1} \\
= \\
\mathbf{3 7 . 9 0}\end{array}$ & $\begin{array}{l}T_{c 1}= \\
49.15\end{array}=$ & $\begin{array}{l}V_{1} \\
= \\
631 \\
.16\end{array}$ & $\begin{array}{l}85 . \\
83\end{array}$ & $\begin{array}{l}I_{1}= \\
115 \\
.22\end{array}$ & $\begin{array}{l}71 . \\
38\end{array}$ & $\begin{array}{l}P_{1}= \\
72 . \\
60\end{array}$ & $\begin{array}{l}61 \\
.2\end{array}$ \\
\hline $\begin{array}{l}X_{2}= \\
12: 4 \\
4: 55 \\
p m\end{array}$ & $\begin{array}{l}\text { PO } \\
A_{2=} \\
916 . \\
81\end{array}$ & $\begin{array}{l}T_{a m b 2} \\
= \\
41.98\end{array}$ & $\begin{array}{l}T_{c 2}= \\
59.97\end{array}=$ & $\begin{array}{l}V_{2} \\
= \\
601 \\
.07\end{array}$ & $\begin{array}{l}81 . \\
73\end{array}$ & $\begin{array}{l}I_{2}= \\
146 \\
.83\end{array}$ & $\begin{array}{l}90 . \\
1\end{array}$ & $\begin{array}{l}P_{2}= \\
88 . \\
04\end{array}$ & $\begin{array}{l}74 \\
.2\end{array}$ \\
\hline $\begin{array}{l}\Delta X= \\
X_{2^{-}} \\
X_{1}= \\
2: 30 \\
\text { hrs }\end{array}$ & $\begin{array}{l}\Delta \mathbf{P} \\
\mathrm{OA} \\
= \\
+\mathbf{1 8} \\
\mathbf{3 . 8}\end{array}$ & $\begin{array}{l}\Delta T_{a m b} \\
= \\
+4.08\end{array}$ & $\begin{array}{l}\Delta T_{c}= \\
+10.82\end{array}$ & $\begin{array}{l}\Delta \mathbf{V} \\
=- \\
30 . \\
09\end{array}$ & $\begin{array}{l}\Delta V \\
\mathrm{r}= \\
- \\
4.0 \\
9\end{array}$ & $\begin{array}{l}\Delta \mathrm{I} \\
= \\
+\mathbf{3 1} \\
.61\end{array}$ & $\begin{array}{l}\Delta I_{r} \\
= \\
+1 \\
9.1\end{array}$ & $\begin{array}{l}\Delta P \\
= \\
+15 \\
.44\end{array}$ & $\begin{array}{l}\Delta \\
P_{r} \\
= \\
+1 \\
3\end{array}$ \\
\hline
\end{tabular}

The results of table clearly show that in the time interval $10: 16: 28$ to $12: 44: 55$, the only time when $V_{d c}$ experiences negative effect of cell temperature.
- POA increases by $183.8 \mathrm{~W} / \mathrm{m}^{2}$.

- Increase in cell temperature is only $10.82{ }^{\circ} \mathrm{C}$.

- Decrease in $\mathrm{V}_{\mathrm{dc}}$ is about $4 \%$ of its maximum rated value but still its value is within $86 \%$ to $82 \%$ of its rated value, which is very high compared to dc voltage at $25^{\circ} \mathrm{C}$.

- Increase in current is about $19 \%$ of its maximum rated value.

- $\mathrm{P}_{\mathrm{dc}}$ increase by $13 \%$ of its maximum rated value, a remarkable increase in $\mathrm{P}_{\mathrm{dc}}$ with increase in temperature.

Thus, high value of irradiance outweighs the negative effect of temperature making dc power output independent of temperature showing extraordinarily overall positive effect of high irradiance and high temperature.

Similar results are obtained for all clear sunny days having high irradiance and high cell temperature although results of $4^{\text {th }}$ June and $11^{\text {th }}$ July have been evaluated randomly.

\subsection{Concurrent effect of temperature and irradiance on $V_{d c}$, $I_{d c}$ and $P_{d c}$, for $4^{\text {th }}$ of June 2016}

The joint effect of irradiance and cell temperature for $4^{\text {th }}$ June can be visualised in figure 6-7 and is evaluated in table 2 .

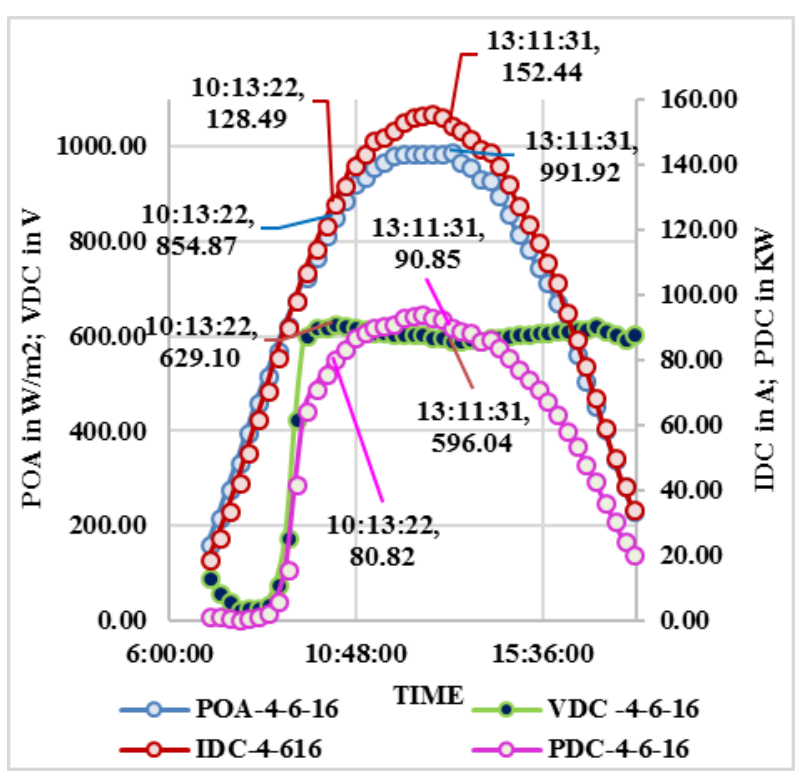

Figure 6- Variation in POA, $V_{d c}, I_{d c}$ and $P_{d c}$ with time for $4^{\text {th }}$ June 2016 


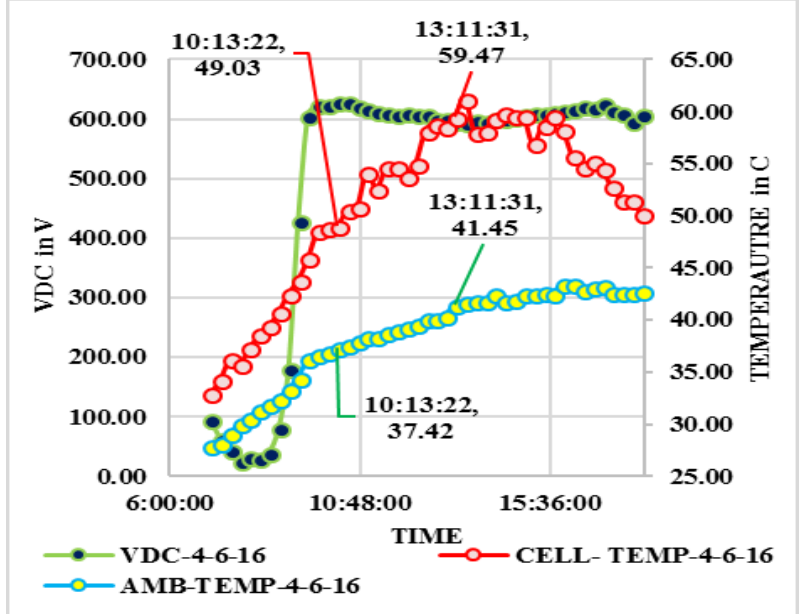

Figure 7- Variation of $V_{d c}, T_{c}$ and $T_{a m b}$ with time for $4^{\text {th }}$ June 2016

Table 2- Evaluation of relative contribution of Irradiance and temperature for $4^{\text {th }}$ of June 2016 on $P_{d c}$ in the time interval when $V_{d c}$ experiences negative effect of temperature.

\begin{tabular}{|c|c|c|c|c|c|c|c|c|c|}
\hline $\begin{array}{l}\text { Tim } \\
\text { e } \\
\text { inter } \\
\text { val }\end{array}$ & $\begin{array}{l}\mathbf{P O} \\
\mathbf{A} \text { in } \\
\mathbf{W} / \\
\mathbf{m}^{2}\end{array}$ & \begin{tabular}{|l|} 
Ambie \\
nt \\
temper \\
ature \\
in $^{\circ} \mathrm{C}$ \\
\end{tabular} & $\begin{array}{l}\text { Cell } \\
\text { temper } \\
\text { ature } \\
\text { in }{ }^{\circ} \mathrm{C}\end{array}$ & $\begin{array}{l}\mathbf{V}_{\mathbf{d c}} \\
\text { in } \\
\mathbf{V}\end{array}$ & $\begin{array}{l}\mathbf{V}_{\mathbf{r}} \\
\text { in } \\
\%\end{array}$ & $\begin{array}{l}\mathbf{I}_{\mathbf{d c}} \\
\text { in A }\end{array}$ & $\begin{array}{l}I_{\mathrm{r}} \text { in } \\
\%\end{array}$ & $\begin{array}{l}\mathbf{P}_{\mathrm{dc}} \\
\text { in } \\
\mathbf{K W}\end{array}$ & $\begin{array}{l}\mathbf{P}_{\mathbf{r}} \\
\text { in } \\
\%\end{array}$ \\
\hline $\begin{array}{l}X_{1}= \\
10: 1 \\
3: 22\end{array}$ & \begin{tabular}{|l|} 
PO \\
$A_{1}=$ \\
854. \\
87 \\
\end{tabular} & $\begin{array}{l}\mathbf{T}_{\mathrm{amb1}}= \\
\mathbf{3 7 . 4 2}\end{array}$ & $\begin{array}{l}T_{\mathrm{c} 1} \\
49.03\end{array}=$ & $\begin{array}{l}V_{1} \\
= \\
629 . \\
10 \\
\end{array}$ & $\begin{array}{l}85 . \\
56\end{array}$ & $\begin{array}{l}I_{1}= \\
128 . \\
49\end{array}$ & 79.7 & $\begin{array}{l}P_{1}= \\
80.8 \\
2\end{array}$ & $\begin{array}{l}68 . \\
1\end{array}$ \\
\hline \begin{tabular}{l|}
$X_{2}=$ \\
$13: 1$ \\
$1: 31$
\end{tabular} & \begin{tabular}{|l|} 
PO \\
$A_{2}=$ \\
991. \\
92 \\
\end{tabular} & $\begin{array}{l}T_{\text {amb2 }} \\
41.45\end{array}=$ & $\begin{array}{l}T_{\mathrm{c} 2} \\
\mathbf{5 9 . 4 7}\end{array}=$ & $\begin{array}{l}V_{2} \\
= \\
596 . \\
04 \\
\end{array}$ & $\begin{array}{l}81 . \\
05\end{array}$ & $\begin{array}{l}I_{2}= \\
152 . \\
44\end{array}$ & $\begin{array}{l}94.4 \\
4\end{array}$ & $\begin{array}{l}P_{2}= \\
90.8 \\
5\end{array}$ & $\begin{array}{l}76 . \\
54\end{array}$ \\
\hline $\begin{array}{l}\Delta \mathbf{X}= \\
\mathbf{X}_{2^{-}} \\
\mathbf{X}_{1}= \\
\text { 3hrs }\end{array}$ & $\begin{array}{l}\Delta \mathrm{PO} \\
\mathrm{A}= \\
+\mathbf{1 3 7} \\
.05\end{array}$ & $\begin{array}{l}\Delta \mathbf{T}_{\mathrm{amb}} \\
= \\
4.03\end{array}+$ & $\begin{array}{l}\Delta T_{c}= \\
+10.44\end{array}$ & $\begin{array}{l}\Delta V \\
=- \\
33.0 \\
6\end{array}$ & $\begin{array}{l}\Delta V \\
r= \\
- \\
4.5 \\
1\end{array}$ & $\begin{array}{l}\Delta I \\
= \\
+23 \\
.95\end{array}$ & $\begin{array}{l}\Delta \mathbf{I}_{\mathrm{r}} \\
= \\
+14 \\
.83\end{array}$ & $\begin{array}{l}\Delta \mathbf{P} \\
= \\
+10 \\
.03\end{array}$ & $\begin{array}{l}\Delta \mathbf{P}_{\mathrm{r}} \\
= \\
+8 . \\
45\end{array}$ \\
\hline
\end{tabular}

The results again confirm remarkable increase in $\mathrm{P}_{\mathrm{dc}}$ with increasing temperature for high value of irradiance and consequently resulting high temperature.

\subsection{Concurrent effect of temperature and irradiance on $V_{d c}, I_{d c}$ and $P_{d c}$ for $11^{\text {th }} \mathrm{July}$ 2016}

The joint effect of irradiance and cell temperature for $11^{\text {th }}$ July can be visualised in figure 8-9 and is evaluated in table 3 .

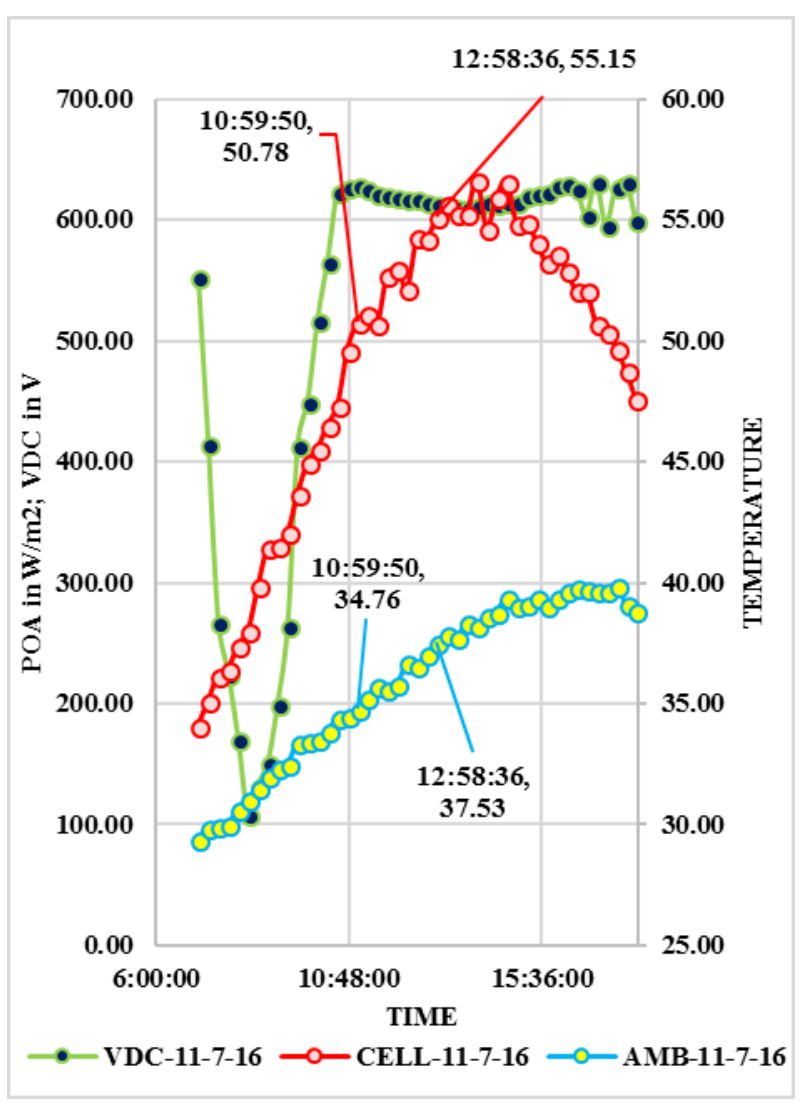

Figure 8- Variation of $V_{d c}, T_{c}$ and $T_{a m b}$ with time for $11^{\text {th }}$ July 2016

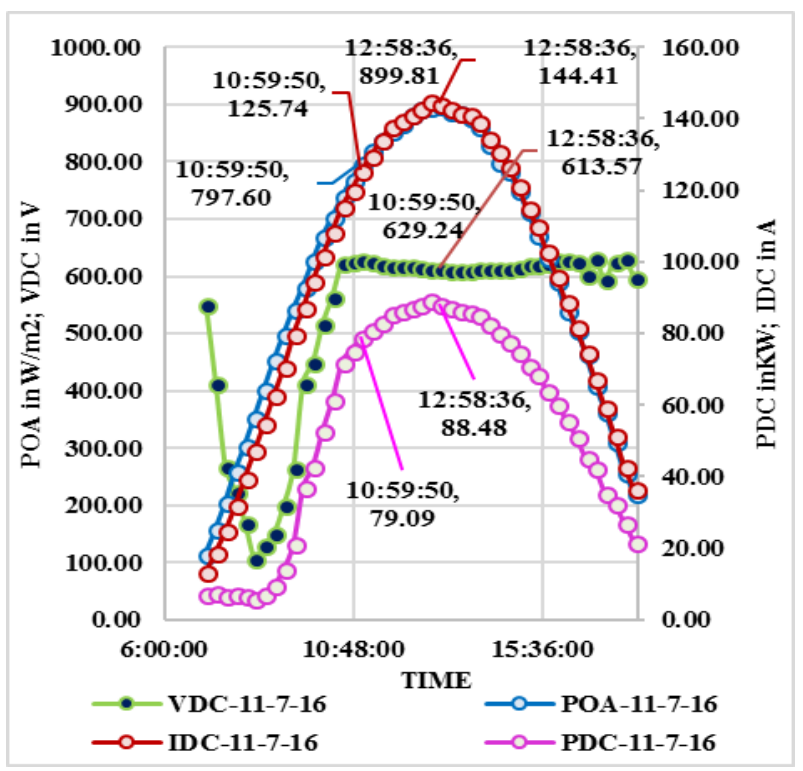

Figure 9- Variation in POA, $\mathbf{V}_{\mathrm{dc}}, \mathbf{I}_{\mathrm{dc}}$ and $\mathbf{P}_{\mathrm{dc}}$ with time for 11th of July 2016 
Table 3- Evaluation of relative contribution of Irradiance and temperature for $11^{\text {th }}$ of July 2016 on $P_{d c}$ in the time interval when $V_{d c}$ experiences negative effect of temperature

\begin{tabular}{|c|c|c|c|c|c|c|c|c|c|}
\hline $\begin{array}{l}\text { Ti } \\
\text { me } \\
\text { int } \\
\text { erv } \\
\text { al }\end{array}$ & $\begin{array}{l}\text { PO } \\
\text { A } \\
\text { in } \\
\mathbf{W} / \\
\mathbf{m}^{2}\end{array}$ & $\begin{array}{l}\text { Amb } \\
\text { ient } \\
\text { temp } \\
\text { erat } \\
\text { ure } \\
\text { in } \\
{ }^{\circ} \mathrm{C}\end{array}$ & $\begin{array}{l}\text { Cell } \\
\text { temp } \\
\text { erat } \\
\text { ure } \\
\text { in } \\
{ }^{\circ} \mathrm{C}\end{array}$ & $\begin{array}{l}V_{d} \\
c \\
\text { in } \\
V\end{array}$ & $\begin{array}{l}\mathrm{V} \\
\mathrm{r} \\
\text { in } \\
\%\end{array}$ & $\begin{array}{l}\mathbf{I}_{\mathbf{d c}} \\
\text { in } \\
\mathbf{A}\end{array}$ & $\begin{array}{l}\mathbf{I}_{\mathbf{r}} \\
\text { in } \\
\%\end{array}$ & $\begin{array}{l}P \\
\text { dc } \\
\text { in } \\
K \\
W\end{array}$ & $\begin{array}{l}P_{r} \\
\text { in } \\
\%\end{array}$ \\
\hline $\begin{array}{l}X_{1} \\
= \\
10: \\
59: \\
50\end{array}$ & $\begin{array}{l}\text { PO } \\
\text { A }_{1} \\
= \\
79 \\
7.6 \\
0\end{array}$ & $\begin{array}{l}T_{a m b} \\
1 \\
34.7 \\
6\end{array}=$ & $\begin{array}{l}\mathbf{T}_{\mathrm{c1}}= \\
\mathbf{5 0 . 7} \\
8\end{array}$ & $\begin{array}{l}V_{1} \\
= \\
62 \\
9 . \\
24\end{array}$ & $\begin{array}{l}8 \\
5 . \\
3 \\
5\end{array}$ & $\begin{array}{l}I_{1} \\
= \\
12 \\
5.7 \\
4\end{array}$ & $\begin{array}{c}77 \\
.9\end{array}$ & $\begin{array}{l}P_{1} \\
= \\
7 \\
9 . \\
0 \\
9\end{array}$ & $\begin{array}{l}66 \\
.6 \\
3\end{array}$ \\
\hline $\begin{array}{l}X_{2} \\
= \\
12: \\
58: \\
36\end{array}$ & $\begin{array}{l}\text { PO } \\
A_{2} \\
=8 \\
99 . \\
81\end{array}$ & $\begin{array}{l}T_{\text {amb }} \\
2= \\
37.5 \\
3\end{array}$ & $\begin{array}{l}\mathbf{T}_{\mathbf{c} 2}= \\
55.1 \\
5\end{array}$ & $\begin{array}{l}V_{2} \\
= \\
61 \\
3 . \\
57\end{array}$ & $\begin{array}{l}8 \\
3 . \\
3 \\
6\end{array}$ & $\begin{array}{l}I_{2} \\
=1 \\
44 . \\
41\end{array}$ & $\begin{array}{l}89 \\
.5\end{array}$ & $\begin{array}{l}P_{2} \\
= \\
8 \\
8 . \\
4 \\
8\end{array}$ & $\begin{array}{l}74 \\
.6\end{array}$ \\
\hline $\begin{array}{l}\Delta \mathbf{X} \\
=\mathbf{X} \\
2^{-} \\
\mathbf{X}_{1} \\
\sim \\
2 \mathbf{h r} \\
\text { s }\end{array}$ & $\begin{array}{l}\Delta \mathbf{P} \\
0 \\
A= \\
+1 \\
02 . \\
21\end{array}$ & $\begin{array}{l}\Delta \\
T_{\text {amb }} \\
= \\
\mathbf{2 . 7 7}\end{array}$ & $\begin{array}{l}\Delta T_{c}= \\
+ \\
\mathbf{4 . 3 7}\end{array}$ & $\begin{array}{l}\Delta \\
V \\
= \\
15 \\
.7\end{array}$ & $\begin{array}{l}\Delta \\
\text { V } \\
\mathbf{u} \\
= \\
- \\
1 . \\
9\end{array}$ & $\begin{array}{l}\Delta I \\
= \\
+1 \\
8.6 \\
7\end{array}$ & $\begin{array}{l}\Delta I \\
r= \\
+1 \\
1 . \\
56\end{array}$ & $\begin{array}{l}\Delta \\
\mathbf{P} \\
= \\
+ \\
9 . \\
4 \\
7\end{array}$ & $\begin{array}{l}\Delta \\
P_{u} \\
= \\
+7 \\
.9 \\
87\end{array}$ \\
\hline
\end{tabular}

The outcomes of table 1-3 undoubtedly illustrate that large variations in irradiance dominates over the sensitivity to temperature and so the dc power increases with increase in temperature.

Table 4- Estimation of average variation in irradiance and temperature and joint effect of two on $V_{\mathrm{dc}}, I_{\mathrm{dc}}$ and $\mathbf{P}_{\mathrm{dc}}$

\begin{tabular}{|c|c|c|c|c|c|}
\hline Date & $\begin{array}{l}\Delta \mathrm{POA} \text { in } \\
\mathrm{W} / \mathrm{m}^{2}\end{array}$ & $\begin{array}{l}\Delta \mathrm{T}_{\mathrm{c}} \text { in } \\
{ }^{\mathrm{O}} \mathrm{C}\end{array}$ & $\begin{array}{l}\Delta \mathrm{V}_{\mathrm{r}} \text { in } \\
\%\end{array}$ & $\begin{array}{ll}\Delta \mathrm{I}_{\mathrm{r}} & \text { in } \\
\% & \end{array}$ & $\begin{array}{ll}\Delta \mathrm{P}_{\mathrm{r}} & \text { in } \\
\% & \end{array}$ \\
\hline $13-05-16$ & $\begin{array}{l}\Delta \mathrm{POA}_{1}= \\
+183.8\end{array}=$ & $\begin{array}{l}\Delta \mathrm{T}_{\mathrm{c1}}= \\
+10.82\end{array}=$ & $\begin{array}{l}\Delta \mathrm{V}_{\mathrm{r} 1}= \\
-4.09\end{array}$ & $\begin{array}{l}\Delta \mathrm{I}_{\mathrm{r} 1}= \\
+19.1\end{array}$ & $\begin{array}{l}\Delta \mathrm{P}_{\mathrm{r} 1}= \\
+13\end{array}$ \\
\hline 4-06-16 & $\begin{array}{l}\Delta \mathrm{POA}_{2} \\
+137.05\end{array}=$ & $\begin{array}{l}\Delta \mathrm{T}_{\mathrm{c} 2} \\
+10.44\end{array}=$ & $\begin{array}{l}\Delta \mathrm{V}_{\mathrm{r} 2}= \\
-4.51\end{array}$ & $\begin{array}{l}\Delta \mathrm{I}_{\mathrm{r} 2}= \\
+14.83\end{array}$ & $\begin{array}{l}\Delta \mathrm{P}_{\mathrm{r} 2}= \\
+8.45\end{array}=$ \\
\hline $11-07-16$ & $\begin{array}{l}\triangle \mathrm{POA}_{3} \\
+102.21\end{array}=$ & $\begin{array}{l}\Delta \mathrm{T}_{\mathrm{c} 3}= \\
+4.37\end{array}=$ & $\begin{array}{l}\Delta \mathrm{V}_{\mathrm{r} 3}= \\
-2.1\end{array}$ & $\begin{array}{l}\Delta \mathrm{I}_{\mathrm{r} 3}= \\
+11.56\end{array}$ & $\begin{array}{l}\Delta \mathrm{P}_{\mathrm{r} 3}= \\
+7.978\end{array}$ \\
\hline Average & $\begin{array}{l}\Delta \mathrm{POA}_{\text {avr }}= \\
+141.02\end{array}=$ & $\begin{array}{l}\Delta \mathrm{T}_{\mathrm{avr}} \\
+8.54\end{array}=$ & $\begin{array}{l}\Delta \mathrm{V}_{\text {avr }}= \\
-3.566\end{array}$ & $\begin{array}{l}\Delta \mathrm{I}_{\mathrm{avr}}= \\
+15.16\end{array}$ & $\begin{array}{l}\Delta \mathrm{P}_{\text {avr }}= \\
+9.8\end{array}$ \\
\hline
\end{tabular}

Where

$\Delta \mathrm{POA}_{\mathrm{avr}}=\left(\Delta \mathrm{POA} 1+\Delta \mathrm{POA}_{2}+\Delta \mathrm{POA}_{3}\right) / 3 ; \Delta \mathrm{T}_{\mathrm{avr}}=\left(\Delta \mathrm{T}_{\mathrm{c} 1}\right.$ $\left.+\Delta \mathrm{T}_{\mathrm{c} 2}+\Delta \mathrm{T}_{\mathrm{c} 3}\right) / 3$

$\Delta \mathrm{V}_{\mathrm{avr}}=\left(\Delta \mathrm{V}_{\mathrm{r} 1}+\Delta \mathrm{V}_{\mathrm{r} 2}+\Delta \mathrm{V}_{\mathrm{r} 3}\right) / 3 ; \Delta \mathrm{I}_{\mathrm{avr}}=\left(\Delta \mathrm{I}_{\mathrm{r} 1}+\Delta \mathrm{I}_{\mathrm{r} 2}+\Delta \mathrm{I}_{\mathrm{r} 3}\right.$ )$/ 3$;

$\Delta \mathrm{P}_{\mathrm{avr}}=\left(\Delta \mathrm{P}_{\mathrm{r} 1}+\Delta \mathrm{P}_{\mathrm{r} 2}+\Delta \mathrm{P}_{\mathrm{r} 3}\right) / 3$;

Variation in irradiance and temperature varies from day to day but for clear sunny days, roughly for every $100 \mathrm{~W} / \mathrm{m}^{2}$ increase in irradiance temperature increases only by $5-6^{\circ} \mathrm{C}$. As a result, $\mathrm{V}_{\mathrm{dc}}$ drops slightly around $2-3 \%$ while Idc increases significantly around $10-11 \%$ and correspondingly $\mathrm{P}_{\mathrm{dc}}$ increases by $7-8 \%$. Thus, the joint effect of two is positive confirming extraordinarily positive effect of high irradiance and high cell temperature.

\subsection{Data analysis for the month of} December, the coldest month of Western

\section{Rajasthan, particularly 22-12-15}

The data for the month of December when Western Rajasthan has low irradiance and low temperature is also analysed to confirm the extraordinary positive effect of high irradiance and high temperature.

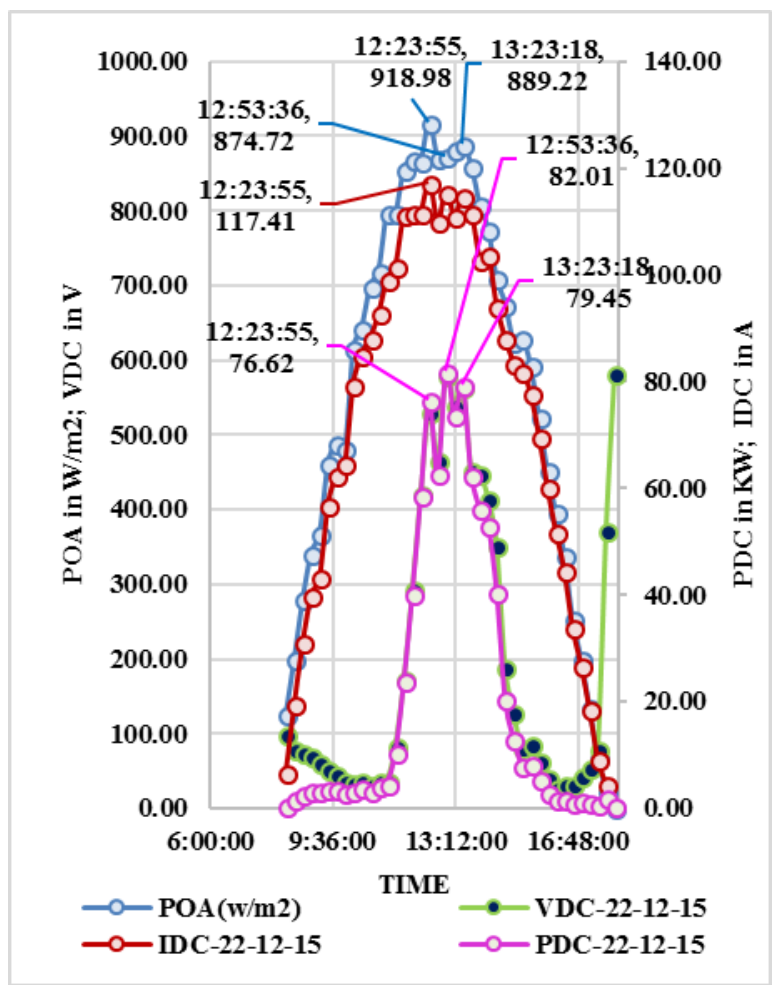

Figure 10- Variation in POA, $\mathbf{V}_{\mathrm{dc}}, \mathbf{I}_{\mathrm{dc}}$ and $\mathbf{P}_{\mathrm{dc}}$ with time for $22^{\text {nd }}$ December 2015

In the month of December as the cell temperature is less than $47^{\circ} \mathrm{C}, \mathrm{V}_{\mathrm{dc}}$ does not attain constant value. It drops rapidly with decreasing POA even though cell temperature starts reducing. $P_{d c}$ varies in accordance to $V_{d c}$ even though $I_{d c}$ varies linearly with POA as variations in $\mathrm{V}_{\mathrm{dc}}$ are large compared to variations in $\mathrm{I}_{\mathrm{dc}}$. High $\mathrm{P}_{\mathrm{dc}}$ is obtained only for very short time. Time interval for which $\mathrm{P}_{\mathrm{dc}}$ is greater than $60 \%$ of its rated value is evaluated in table 5 .

Table 5- Evaluation of time duration for which $P_{d c}$ is greater than $60 \%$ of its rated value

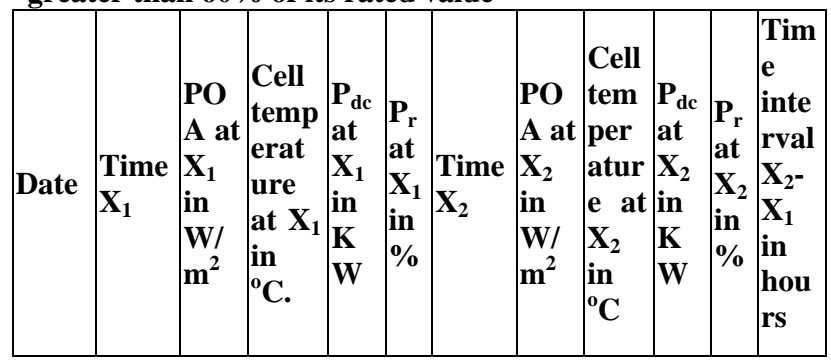




\begin{tabular}{|c|c|c|c|c|c|c|c|c|c|c|c|}
\hline $\begin{array}{l}13.05 \\
.16\end{array}$ & $\begin{array}{l}10: 16 \\
: 28\end{array}$ & $\begin{array}{l}733 . \\
01\end{array}$ & 49.15 & $\begin{array}{l}72 . \\
60\end{array}$ & $\begin{array}{l}61 \\
.2\end{array}$ & $\begin{array}{l}15: 13 \\
: 23\end{array}$ & $\begin{array}{l}727 . \\
12\end{array}$ & $\begin{array}{l}59.3 \\
7\end{array}$ & 71. & 60 & $\tilde{0}$ \\
\hline 66 & $\begin{array}{l}\text { 9:43: } \\
41\end{array}$ & $\begin{array}{l}772 . \\
61\end{array}$ & 62 & $\begin{array}{l}71 . \\
66\end{array}$ & $\begin{array}{l}60 \\
.4\end{array}$ & $\begin{array}{l}15: 25 \\
: 07\end{array}$ & $\begin{array}{l}751 . \\
45\end{array}$ & $\begin{array}{l}58.7 \\
5\end{array}$ & $\begin{array}{l}71 . \\
44\end{array}$ & $\begin{array}{c}60 \\
.2\end{array}$ & $\tilde{8}$ \\
\hline & $\mid \begin{array}{l}10: 30 \\
: 09\end{array}$ & \begin{tabular}{|l|}
740. \\
13
\end{tabular} & 7.36 & $\begin{array}{l}72 . \\
15\end{array}$ & $\begin{array}{l}60 \\
.8\end{array}$ & $\begin{array}{l}15: 12 \\
: 13\end{array}$ & $\begin{array}{l}716 \\
44\end{array}$ & $\begin{array}{l}54.9 \\
4\end{array}$ & $\begin{array}{l}71 . \\
51\end{array}$ & $\begin{array}{l}60 \\
.3\end{array}$ & $\begin{array}{l}24: \\
2\end{array}$ \\
\hline 5 & :23 & $\begin{array}{l}918 \\
98\end{array}$ & .58 & $\begin{array}{l}76 . \\
62\end{array}$ & $\begin{array}{l}64 \\
.6\end{array}$ & $\begin{array}{l}13: 23 \\
: 18\end{array}$ & $\begin{array}{l}889 \\
22\end{array}$ & $\mid \begin{array}{l}41.7 \\
2\end{array}$ & $\begin{array}{l}79 . \\
45\end{array}$ & & $\mid \begin{array}{l}\mathbf{1} \\
0\end{array}$ \\
\hline
\end{tabular}

Table 5 clearly shows that for the clear sunny days having long duration of high irradiance and consequently high temperature, $\mathrm{P}_{\mathrm{dc}}$ is greater than $60 \%$ of its rated value for 5-6 hours. On the other hand, in winters when high irradiance exists for very short duration, the subsequent cell temperature is also lower so $\mathrm{P}_{\mathrm{dc}}$ greater than $60 \%$ of its rated value is obtained only for one hour. Further when $P_{d c}$ is greater than $60 \%$ of its rated value, the corresponding cell temperature is in the range of $49-62^{\circ} \mathrm{C}$. In winters when cell temperature is low, higher Pdc is obtained for much higher value of POA, the reason being that although $\mathrm{I}_{\mathrm{dc}}$ varies in direct proportion to POA, higher $\mathrm{V}_{\mathrm{dc}}$ is obtained only for cell temperature greater than $48-49^{\circ} \mathrm{C}$. Maximum $\mathrm{P}_{\mathrm{dc}}$ equal to $94.68 \mathrm{KW}$ that is $80 \%$ of its maximum rated value is obtained on 4 th of June at cell temperature $58.14^{\circ} \mathrm{C}$. In fact, $\mathrm{P}_{\mathrm{dc}}$ greater than $60 \%$ of its rated value is obtained for POA greater than $730 \mathrm{~W} / \mathrm{m}^{2}$ and cell temperature greater than $48-49^{\circ} \mathrm{C}$. Thus, despite slight negative effect of high cell temperature, high irradiance and high cell temperature in the range of $48-62^{\circ} \mathrm{C}$ has substantial positive effect on $\mathrm{P}_{\mathrm{dc}}$.

\section{RESULT}

The multicrystalline PV module gives excellent performance at high cell temperature and high irradiance.

- The cell temperature is directly proportional to irradiance.

- One of the most significant positive aspect of high cell temperature is that $\mathrm{V}_{\mathrm{dc}}$ attains high nearly $86-80 \%$ of its rated value for cell temperature in the range of $48-62^{\circ} \mathrm{C}$.

- At high irradiance and subsequently resulting high temperature variations in POA are prominent compared to variations in cell temperature, the result is irradiance dominates over the negative effect of cell temperature.

- Long duration of high POA is bound to increase cell temperature to a very high value. The result is high $\mathrm{V}_{\mathrm{dc}}$ due to high $\mathrm{T}_{\mathrm{c}}$, high $\mathrm{I}_{\mathrm{dc}}$ due to high POA leading to high $\mathrm{P}_{\mathrm{dc}}$ for 5-6 hours.

- Shorter duration of high POA results in lower cell temperature as change in panel temperature cannot be instantaneous. The result is lower $\mathrm{V}_{\mathrm{dc}}$ at lower $\mathrm{T}_{\mathrm{c}}$, high $\mathrm{I}_{\mathrm{dc}}$ for short duration leading to high $\mathrm{P}_{\mathrm{dc}}$ for only one hour.

- $\mathrm{P}_{\mathrm{dc}}$ greater than $60 \%$ of its maximum rated value is obtained for cell temperature in the range of $48-62^{\circ} \mathrm{C}$.

- At lower cell temperature high value of $\mathrm{P}_{\mathrm{dc}}$ is obtained for correspondingly high value of POA.

In contrast to literature and research papers, all the above points signify extraordinarily positive effect of high cell temperature and high irradiance on dc power output which directly governs the efficiency of a PV power plant. The above results have been evaluated for the climatic conditions of Western Rajasthan and it can be predicted that above results will hold true for all sites having clear sunny sky with high insolation.

\section{CONCLUSION}

In contrast to negative effect of cell temperature greater than $25^{\circ} \mathrm{C}$ cited in literature and research papers the results of this paper confirm to extraordinary positive effect of high cell temperature a consequence of high irradiance on the performance of a multicrystalline PV module. The negative effect of cell temperature on $V_{\mathrm{dc}}$ itself is insignificant which is further overruled by substantial increase in irradiance. In fact, cell temperature greater than $49^{\circ} \mathrm{C}$ and POA greater than 750 $\mathrm{W} / \mathrm{m}^{2}$ are required to obtain high energy yield. The efficiency of plant being directly proportional to dc power increases significantly for cell temperature greater than $49^{\circ} \mathrm{C}$ and POA greater than $750 \mathrm{~W} / \mathrm{m}^{2}$. Use of low cost reflector and concentrators in countries having lower irradiance and temperature or in winters in Western Rajasthan can increase the efficiency of plant considerably. As further work solar energy conversion efficiency, efficiency of PV solar power plant for multicrystalline and other types of photovoltaic cells in different seasons of Western Rajasthan needs to be evaluated. Also, seasonal and annual performance prediction of PV plants for the climatic conditions of Western Rajasthan and way to enhance the performance are to be done. In addition, viability and impact of use of reflectors and concentrators need to be analysed.

\section{ACKNOWLEDGMENT}

The authors would like to acknowledge the support of Shri J. K. Borgohain, Executive Director, Rajasthan Project. Oil India Lmt., Jodhpur, Shri D. C. Gogoi, Head, Technical Service, Oil India Lmt, Jodhpur; Shri Rajesh Kundoo, Incharge, PV Power Plant at Ramgarh, Jaisalmer in conducting this study.

\section{REFERENCES}

[1] Attari. K. Yaakoubi. A. E. Asselman. A. Comparative Performance Investigations between photovoltaic system for two different cities. 10th International conference inter disciplinary in Engineering, Inter-Eng 2016. Procedia Engineering 181 (2017) 810-817. Available online at www.sciencedirect.com.

[2] Huld. T. and Gracia, Amillo. A. M. Estimating PV Module Performance over Large Geographical Regions: The Role of Irradiance, Air Temperature, Wind Speed and Solar Spectrum. Energies 2015, 8, 5159-5181; www.mdpi.com/journal/energies.

[3] Bhattacharya. T. Chakraborty. A. K and Pal. K. Effects of Ambient Temperature and Wind Speed on Performance of Monocrystalline Solar Photovoltaic Module in Tripura, India. Hindawi Publishing Corporation, Journal of Solar Energy, Volume 2014, Article ID 817078, 5 pages.

[4] Vasisht. M. S. Srinivasan J. Ramasesha, S K. "Performance of solar photovoltaic installations: Effect of seasonal variations." Solar Energy 131 (2016) 39-46. www.sciencedirect.com

[5] Garg, S. and JB, Arun. 2016. High Temperature Effect on Multicrystalline Photovoltaic Module in Western 
Rajasthan, India. Communications on Applied Electronics (CAE) - ISSN: 2394-4714 Foundation of Computer Science FCS, New York, USA, Volume 4 No.2, January 2016 - www.caeaccess.org.

[6] Garg, S. JB, Arun and Surana, D. C. 2016. Performance of a Multicrystalline Photovoltaic Module in Critical Climatic Conditions of Western Rajasthan, India. Communications on Applied Electronics (CAE) - ISSN : 2394-4714. Foundation of Computer Science FCS, New York, USA, Volume 5- No.4, June 2016 www.caeaccess.org

[7] Garg, S. and JB, Arun. 2017. Evaluating DC Voltage Temperature Coefficient of a Multicrystalline Module in Actual Environmental Conditions of Western Rajasthan, India Communications on Applied Electronics (CAE) ISSN : 2394-4714 Foundation of Computer Science FCS, New York, USA Volume 7 - No. 6, September 2017 www.caeaccess.org

[8] Mustapha. I. Dikwa M. K. Musa B. U and Abbagana M. Performance evaluation of polycrystalline solar photovoltaic module in weather conditions of Maiduguri,
Nigeria. Arid Zone Journal of Engineering, Technology and Environment. August, 2013; Vol. 9, 69-81.

[9] N. Ciprian, M. Florin, A. Dragos. Annual Energy harvest of LACARP photovoltaic Systems. $6^{\text {th }}$ International conference on modern Power systems MPS 2015, 18-21 May 2015, Cluj -Napoca, Romania

[10] Babatunde, A. A, Abbasoglu, S. Evaluation of field data and simulation results of a photovoltaic system in countries with high solar radiation. Turkish Journal of Electrical Engineering \& Computer Sciences. August 2014.

[11] Panagea, S. I, Tsanis, K.I Koutroulis, G.A. and. Grillakis, G.M. Climate Change Impact on Photovoltaic Energy Output: The Case of Greece. Hindawi Publishing Corporation Advances in Meteorology Volume 2014, Article ID 264506, 11 pages http://dx.doi.org/10.1155/2014/264506

[12] Masters, G. M. Renewable and efficient electric power systems. Wiley Interscience. 2004.

[13] Mayfield, R. Photovoltaic design and installation for dummies. Wiley Publishing Inc. 2010. 